\title{
Lung Cancer Stem Cells and Cancer Stem Cell-targeting Natural Compounds
}

\author{
ARNATCHAI MAIUTHED ${ }^{1,2}$, WIPA CHANTARAWONG ${ }^{2}$ and PITHI CHANVORACHOTE ${ }^{1,2}$ \\ ${ }^{1}$ Department of Pharmacology and Physiology, Faculty of Pharmaceutical Sciences, and \\ ${ }^{2}$ Cell-based Drug and Health Products Development Research Unit, Chulalongkorn University, Bangkok, Thailand
}

\begin{abstract}
The novel information regarding molecular and translational research have created a paradigm shift in the understanding of lung cancer biology, revealing the more precise target for anti-cancer drug discovery. Lung cancer is a leading cause of cancer death worldwide accounting for approximately 1 in 5 of all cancer-related deaths. The most important causes of death in such a cancer involves the treatment failure as well as the spreading of cancer cells to distant sites which the cancer stem cell (CSC) within the tumor is accepted as a key driver. CSC is a rare special population of cancer cells exhibiting high tumorigenic properties together with self-renewal and differentiation capability. CSC is not only linked with high tumor-initiating activity, but is also implicated in chemotherapeutic resistance, metastasis, epithelial to mesenchymal transition, and recurrence. Thereafter, novel therapeutic strategies targeting these CSCs are considered in order to improve long-term clinical outcome. Here, we provide sufficient data regarding the biology of CSC in lung cancer, known CSC markers and cellular signals, and promising compounds targeting the stem cell signals in lung cancer that may benefit the development of novel anti-cancer treatment.
\end{abstract}

This article is freely accessible online.

Correspondence to: Pithi Chanvorachote, Ph.D., Department of Pharmacology and Physiology, Faculty of Pharmaceutical Sciences, and Cell- based Drug Health Product Development Research Unit, Chulalongkorn University, Pathumwan, Bangkok, 10330, Thailand. Tel: +662 2188344, Fax: +662 2188340, e-mail: pithi_chan@yahoo.com, pithi.c@chula.ac.th; Wipa Chantarawong, Ph.D., Cell-based Drug Health Product Development Research Unit, Chulalongkorn University, Pathumwan, Bangkok, 10330, Thailand. E-mail: chantarawong.wp@ gmail.com

Key Words: Cancer stem cell, lung cancer, targeting, natural product, review.
Lung cancer has been long recognized as a life-threatening cancer for several years. The death rate of such a cancer is very high in comparison to that of other cancers comprising approximately $20 \%$ of the world's cancer related deaths (1). A total of approximately 1.8 million new cases of lung cancer were estimated in 2012 and this number accounted for $13 \%$ of all new cancer cases (1). Generally, more than three-fourths (nearly $80 \%$ ) of all lung cancers are non-small cell lung cancers (NSCLC) and the rest are small cell lung cancers (SCLC) (2). NSCLC can be further classified to adenocarcinoma, squamous cell carcinoma, and large cell carcinoma (2). Worldwide, a very high number of NSCLC new cases are diagnosed annually and the five-year survival is only about $17.8 \%$. Therefore, the NSCLC is considered very lethal with both high incidence and low survival. NSCLC is frequently found in the elderly population and smoking is accounted as the most important risk factor in most patients (3). Other contributory factors are exposure to environmental toxicants including asbestos, radon, and certain metals such as arsenic, cadmium, and chromium (4). In addition, the exposure to organic chemicals found in coal smoke and fuel burning have been reported to be the risk factors of lung cancer (5).

The concept of cancer stem cells (CSC) was introduced in 1977 (6) and has now become a very interested topic in cancer research. CSCs are a small rare fraction (in most solid tumor $<1 \%$ ) of the whole cancer cell population that exhibit high tumorigenic potential (7). CSCs were first recognized as cancer initiating cells as they are believed to be the root cause or seed of cancer $(8,9)$. The characteristics of CSCs which play pivotal role in driving aggressiveness of cancer include their self-renewal capacity, differentiation (asymmetric cell division), high invasion and migration characteristics, high tumorigenicity, and resistance to chemotherapy (10). Based on such information, CSCs are thought to be the main mediators of all cancer hallmarks including high tumorigenic, high metastasis potential, evading from immune system, resistance to chemotherapy, and cancer relapse $(8,9)$. 
The knowledge at the present day has pointed that the currently used therapeutic approaches comprising surgery, radio-, chemo-, and targeted therapy, in particular for lung cancer management have failed to eradicate the CSC population, a main cause of disease relapse. Natural productderived compounds that specifically target these CSCs could unravel a more precise and efficient way to eradicate this disease.

In addition, the better understanding of CSC biology in relevant to the basic mechanisms enhancing CSC properties and aggressive behaviors of lung and other high mortality cancers may influence the development of cancer management strategies including anti-metastatic, control of CSC activities, and inhibition of cancer relapse.

\section{Cancer Stem Cell in Lung Cancer}

It is now well accepted that lung cancer is characterized by a heterogeneity of cancer cells which exhibit different cell phenotypes as resulted from their distinct cellular signaling.

Among the different lineage of cancer cells residing in the tumor, there is a specific small population of cancer cells that has stem cell characteristics including the self-renewal capacity and multi-lineage differentiation $(11,12)$. Nevertheless, the cancer cells containing the stem cell capacities exhibit highly aggressive phenotypes such as tumorigenic potency, migration and invasion, evading from anoikis, and chemotherapeutic resistance $(9,12-14)$. These specific subpopulation of cancer cells were first named "cancer initiating cells", as they were believed to be the beginning seed of the whole cancer and have now become the main focus of cancer cell biology as well as anti-cancer drug discovery researches.

CSCs were first identified in acute myeloid leukemia (AML) by their cell surface marker CD34+Cd38-. These cells were shown to have a high capacity to self-renew in bone marrow and differentiate to leukemic cells when transplanted into severe combined immunodeficient (SCID) mice (15). After these observations were made, CSCs of various cancer types including lung cancer were discovered through specific cell-surface proteins by numerous research groups (16). However, recent studies suggested that not only CSCs but also certain populations of cancer cells within tumors can have stem cell properties (stemness) (17). Moreover, fully differentiated cancer cells can be transformed to be cancer stem-like cells (CSC-like cells) by the activity of certain cancer microenvironment substances such as nitric oxide, hypoxia condition, and interleukin (1820 ) or by the mutation of specific gene including TP53 (21, 22). These indicated that "stemness" is a phenotype which can be acquired via proper extracellular stimulation signals or accumulation of specific gene mutations within the cells. Nevertheless, both CSC and CSC-like cells show the same characteristics as normal stem cells.
The key CSC properties compose of:

- Self-renewal capacity; an unique ability of the CSC (just like normal stem cells) to generate the identical daughter cells with identical stem cell characteristics.

- Ability to drive tumor heterogeneity and survival of tumor; an ability to differentiate into different cancer cell linages, facilitate cell growth, and survival of whole tumor.

- High tumorigenic potential; an ability of CSC to proliferate and create non-CSC lineages and form new tumors.

Based on the discovery of CSC in lung cancer together with the knowledge from clinical pathology, lung cancer is well recognized as a disease of heterogeneity. Researches have shown that the cancer cells derived form same tumor have a distinct ability to form tumor spheroid in vitro as well as in vivo $(23,24)$. Cancer cells within the same tumor have diverse cellular properties and signaling resulting from the accumulation of genetic mutations and epigenetics alterations. These differences in cellular properties and signaling are associated with plasticity and heterogeneity of cancer stem cells which could be identified by certain biomarkers.

\section{Cancer Stem Cell Markers and Regulatory Proteins}

As CSCs maintain high stem cell signaling that is similar to that in normal tissues, certain cellular markers used for the identification of normal stem cells are also utilized for CSC identification. For lung cancer, the well-recognized CSC markers are summarized in Table I and described as followed.

Cluster of differentiation-133 (CD133, prominin-1, PROM1). CD133 is an 865 amino acids penta-span transmembrane protein which has been accepted as a principle marker of stemness in several solid tumors (25). In human, this protein is a $120 \mathrm{kDa}$ protein product of a single-copy gene on chromosome 4 (4p15.32) (25). In general, CD133 is an important marker used for the isolation and identification of the stem cells from normal tissue like human hematopoietic stem cells $(26,27)$. The function of CD133 in the cells is not fully known yet but several studies have shown that CD133 expression is linked with stem and progenitor cell characteristics as well as the stage of cell regeneration and differentiation (27). Emerging evidence has also shown that CD133 is involved in cell growth and development (28).

In cancers, evidence has shown that the expression of CD133 is associated with tumor aggressiveness through upregulation of certain proteins (29-32).

Later on, evidence has shown that CD133 is not only a biomarker and is functioning in normal stem cells, but also in cancer cells. Expression of CD133 has been used for the identification of CSC in several cancers including lung (33), pancreatic adenocarcinoma (34), hepatocellular carcinoma (35), prostate (36), neural (37), colorectal (38), and renal 
Table I. Cancer stem cell marker for lung cancer.

\begin{tabular}{|c|c|}
\hline Cancer stem cell marker & Description and Function \\
\hline Aldehyde dehydrogenase isoform 1 (ALDH1) & $\begin{array}{l}\text { - Cytosol protein involving in aldehyde detoxification. } \\
\text { - } \quad \text { Protection of stem cells against the against oxidative aldehydes. } \\
\text { Marker for poor prognosis in lung cancer. }\end{array}$ \\
\hline CD133 (prominin-1) & $\begin{array}{l}\text { A cell-surface glycoprotein. } \\
\text { - Role in lung cancer is still unclear. } \\
\text { - May acts as an organizer of cell membrane topology. } \\
\text { Marker for poor prognosis in lung cancer. }\end{array}$ \\
\hline CD44 & $\begin{array}{l}\text { A cell-surface glycoprotein involves in cell to cell interactions, } \\
\text { adhesion and motility of cells. } \\
\text { A receptor for several extracellular matrix component including } \\
\text { hyaluronic acid, collagens, osteopontin, and matrix } \\
\text { metalloproteinases. }\end{array}$ \\
\hline $\begin{array}{l}\text { CD166 (activated leukocyte cell adhesion molecule } \\
\text { (ALCAM)) }\end{array}$ & $\begin{array}{l}\text { A transmembrane glycoprotein member of the immunoglobulin } \\
\text { superfamily of proteins. } \\
\text { Control cell clustering and cell migration }\end{array}$ \\
\hline Wnt/ $\beta$-catenin (canonical Wnt pathway) & $\begin{array}{l}\text { Wnt pathway that stabilizes and causes a cellular } \beta \text {-catenin } \\
\text { accumulation. The } \beta \text {-catenin then translocates into the nucleus and } \\
\text { acts as a transcriptional coactivator of transcription factors that } \\
\text { belong to the TCF/LEF family. } \\
\text { - } \quad \text { Controls embryonic development and adult homeostasis. } \\
\text { Essential for stem cell properties. } \\
\text { - Participates in CSC phenotypes in lung cancer. } \\
\text { Marker for poor prognosis in lung cancer. }\end{array}$ \\
\hline $\begin{array}{l}\text { Octamer-binding transcription factor } 4 \text { (Oct } 4 \text {, } \\
\text { POU5F) }\end{array}$ & $\begin{array}{l}\text { - A homeodomain transcription factor of the POU family. } \\
\text { - } \text { cells. } \\
\text { Absolutely required for the stemness properties of murine and } \\
\text { primate embryonic stem cells. } \\
\text { Essential for somatic cell reprogrammation. } \\
\text { - Participate in the tumorigenicity and malignancy of non-small } \\
\text { cell lung cancer (NSCLC). } \\
\text { Associated with gefitinib resistance in NSCLC. }\end{array}$ \\
\hline Nanog & $\begin{array}{l}\text { A transcription factor involves with self-renewal of undifferentiated } \\
\text { embryonic stem cells. } \\
\text { Important for inner cell mass and embryonic stem (ES) cells } \\
\text { proliferation and self-renewal. } \\
\text { - Marker for poor prognosis in lung cancer. }\end{array}$ \\
\hline Sex determining region Y-box 2 (Sox2) & $\begin{array}{l}\text { A member of the SoxB1 transcription factor family } \\
\text { Important transcription factor in pluripotent stem cells (PSCs). } \\
\text { Function with Oct } 4 \text { and Nanog to control gene expression in PSCs } \\
\text { and maintain stem cell properties. }\end{array}$ \\
\hline $\begin{array}{l}\text { ATP-binding cassette sub-family G member } \\
2 \text { (ABCG2, BRCP, ABCP, MXR) }\end{array}$ & $\begin{array}{l}\text { A constitutively expressed ATP-binding cassette }(\mathrm{ABC}) \text { transporter } \\
\text { that protects many tissues against xenobiotic molecules. } \\
\text { - Controls porphyrin homeostasis. } \\
\text { - Involves in drug resistance mechanism of cancer cells. }\end{array}$ \\
\hline
\end{tabular}

cancers (39). In particular, CD133 is frequently used for indicating stemness in lung cancer following immunehistochemical analysis of non-small cell lung cancer (NSCLC) (29) or small cell lung cancer (SCLC) (40) patient samples. Subsequent transplantation of CD133+cells cultured from these tumors into severe combined immune-deficient (SCID) mice generated tumor xenografts phenotypically identical to the original tumor. 
Cluster of differentiation-44 (CD44). CD44 is 742 amino acids cell surface glycoprotein member of the tumor necrosis factor receptor superfamily. In human, this protein is approximately $80-95 \mathrm{kDa}$ and is the product of the gene in the short arm of chromosome $11(11 \mathrm{p} 13)$. This protein is implicated in the activities of several types of cells including hematopoietic, epithelial, endothelial, and tumor cells (41). The function of CD44 is involved in multiple cellular processes such as cell growth and differentiation, cellular movement, angiogenesis and release of protease enzyme from cell membrane (41). The activation of CD44 by heterodimerization with growth factor receptors (EGFR, FGFR, HGFR, VEGFR, TGF- $\beta$ R) leads to the activation of PI3K-AKT and MAPK pathways (42). CD44 has been recognized as a marker for lung cancer stem cells (43) by analyzing the CSC marker expression in 10 NSCLC related to CSCs properties (43). Moreover, CD44 positive cell has high tumorigenicity in transplantation, increased capacity to resist to chemotherapy, and higher expression of stem cell transcription factor Oct-4 and Nanog. However, analysis of lung tumor samples by immunohistochemical revealed that CD44 expression was a prognostic marker only in adenocarcinomas but not in squamous cell carcinomas.

Aldehyde dehydrogenases 1AI (ALDHIAl). Aldehyde dehydrogenase (ALDH) is a member of a group of enzymes that catalyze the oxidation of aldehydes to carboxylic acids. ALDH1A1 is 501 amino acid protein member of the ALDH1 family and is also known as retino aldyhyde dehydrogenase 1 (RALDH1). In human, this protein is an approximately 55 $\mathrm{kDa}$ protein, product of the ALDHIAl gene located in chromosome 9 (9q21.13). ALDH1A1 is a putative hematopoietic stem cell marker associated with increased drug resistance in many cancers (44). ALDH1A1 has been used to develop the assay named "Aldefluor assay" which is used to distinguish stem and progenitor cells from normal cells. This assay also has been used in the identification of potential CSCs in leukemia, breast, neural, head and neck, colon, liver and lung cancers (45). More recently, lung CSCs have been identified using this method (46). NSCLC cells with relatively high ALDH1 activity, displayed in vitro features of CSCs, including an increased capacity for proliferation, self-renewal, differentiation and expression of the CSC surface marker, CD133 $(47,48)$. Xenograft transplantation of these cells in NOD/SCID mice demonstrated increased tumorigenicity, in addition to increased ALDH1 protein expression which correlated with poor clinical outcome and advanced stage of disease in NSCLC.

ATP-binding cassette sub-family $G$ member 2 (ABCG2). ABCG2 (BRCP, ABCP, MXR) is the member of ATP binding cassette (ABC) superfamily that consists of transmembrane proteins. ABCG2 is 655 amino acids with approximately $72 \mathrm{kDa}$ protein product of a gene in chromosome 4 (4q22). ABCG2 is a half-transporter predominantly localized at plasma membranes, while dimerization is required for active function (49). The side population phenotype (SP) is one well-known characterization method of CSC. This method measures the ability of stem cells to efflux the fluorescent dye Hoechst 33342 from the cells. ABCG2 has been proved to be a molecular determinant responsible for SP phenotype (50). ABCG2 expression is a conserved feature of stem cells from a wide variety of tissues, including pancreas, lung, limbal epithelium, heart, testis, muscle, cornea and conjunctiva, brain, prostate, and embryo (51). Moreover, ABCG2 was high frequently identified in various types of cancer including carcinomas of the digestive tract, lung, breast, ovarian, and melanoma (49). The expression level of ABCG2 is also associated with high pathological grade of tumor and poor prognosis outcome of patients $(52,53)$.

Transcription factors regulating cancer stem cells. CSCs characteristics are thought to be regulated by the numerous set of molecular signals that are tightly controlled by stem cell transcription factors which enrolled the activity to maintain normal stem cell functions. There are several wellcharacterized stem cell transcription factors that are used for CSC identification, and among them Octamer-binding transcription factor 4 (Oct-4), Sex determining region Y-box 2 (Sox2), and Nanog are intensively used for lung CSC identification.

Octamer-binding transcription factor 4 (Oct-4). Oct-4 is a POU domain-containing transcription factor that binds to the octamer sequence, ATGCAAAT, of the target genes. Oct- 4 is encoded by POU5F1 gene located at chromosome 6p21.31. The human Oct- 4 gene consists of five exons which can be spliced into three main isoforms OCT4A, OCT4B and $O C T 4 B 1$. These gene isoforms provide four isoform proteins Oct4A, Oct4B-190, Oct4B-265, and Oct4B-164. All forms of Oct- 4 are functionally and structurally divided into three domains including an $\mathrm{N}$-terminal transcriptional activation domain, a central POU domain, and a C-terminus containing a cell type-specific transactivation domain. Oct $4 \mathrm{~A}$, is generally referred as Oct- 4 , and regulates the stemness of embryonic stem cells. Oct-4 is highly expressed in embryonic stem (ES) cells and low expressed when ES cell differentiates and there is consequently loss of pluripotency. Oct- 4 and its activities were shown to be required for maintaining the ES cell capacity (54). Several target genes of Oct-4 in ES cells have been identified, including Fgf4, Utf1, Opn, Rex1/Zfp42, and Fbx15 (55). Additionally, high levels of Oct-4 have been identified in highly aggressive tumors, poor prognosis patients, and relapse cancer. It has been documented that overexpression of Oct- 4 is associated with tumorigenicity, 
metastasis, and cancer relapse in certain cancers (56). High expression of Oct-4 was detected in prostate and breast cancer stem cells and in the tumor initiating cells in a p53-/- tumor mice model (57). Oct-4 level and activity are known to be regulated by several steps, such as transcription, translation, and post-translational modifications. The key regulatory control of Oct-4 is found to be the post-translational modifications via phosphorylation. Oct-4 can be phosphorylated by various types of protein kinases at Ser229, Ser236 and tyr327. Phosphorylation at these residues regulates Oct-4 stability and transcriptional activity (58, 59). Ubiquitination is the main pathway responsible for eliminating short-lived proteins. Oct- 4 can be ubiquitinated by an HECTtype E3 ubiquitin ligase, Wwp2. Wwp2 regulates Oct-4 level by mediating its ubiquitination and degradation during ESC differentiation. Both the Wwp2 and Oct4 levels decrease when ESCs are induced to differentiate (60). The small ubiquitinrelated modifier (SUMO), which is functionally divergent from ubiquitin, can modify many nuclear proteins to affect their subcellular localization, thus altering their interaction with cooperative molecules. Studies show that Oct-4 can be sumoylated at a single lysine, lysine 118, which is located at the end of the N-terminal transactivation domain and next to the POU DNA-binding domain. Sumoylation of Oct-4 significantly increases its stability, DNA binding, and thus the transcriptional activity (59).

Sex determining region Y-box 2 (Sox2). SRY (sex determining region Y)-box2, Sox2, is a member of the Sox transcription factor of HMG-family that occupies many gene targets including self-renewal maintaining genes (61). Sox2 shares an approximately 80 amino acids region with its family known as high-mobility group (HMG) box domains which are DNA binding domains (62). Sox 2 and Oct- 4 cooperative to activate gene transcription by binding at non-palindromic sequences. In normal tissue, Sox 2 regulates the morphogenesis of various tissue types including control branching morphogenesis of the bronchial tree and maturation of the epithelium of airways, development of gastric and intestinal basal cells, and growth and differentiation of neuronal cells. The amplification of DNA at 3q26.3 region which encodes the Sox 2 gene is frequently observed in NCLCs squamous cell carcinoma. Sox 2 expression is also observed in high grade prostate cancer, colorectal cancer and breast cancer (63). Additionally, overexpression of Sox 2 is associated with chemo-resistance, cancer migration and anchorage-independent growth (63). The regulation of Sox2 level and transcriptional activity are found to be mainly by post-translational modifications. Sox 2 can decrease its DNA binding capacity by sumoylation at lysine 247 which is triggered by phosphorylation at triplet serine (ser249, 250, and 251). Therefore, phosphorylation at Thr118 promotes Sox 2 stability by blocking its ubiquitination. In addition,
Sox 2 is directly methylated at $\operatorname{Arg} 113$ by protein arginine methyltransferase 4 (PRMT4, known as CARM1). This methylation promotes Sox2 self-association via HMG-box domain. The acetylation by p300/cAMP-response elementbinding protein (CBP) at Lys75 of Sox 2 promotes its proteasomal degradation (59).

Nanog. Nanog is a 350 amino acid protein with a homeoboxcontaining motif which facilitates binding with DNA. Nanog is encoded by the NANOGl gene, located on chromosome 12 (12p13.31), which is activated to maintain the pluripotent state of the cell. Based on the differences in gene expression between wild-type and Nanog null cells, it has been proposed that Nanog regulates pluripotency mainly as a transcription repressor for downstream genes that are important for cell differentiation such as Gata4 and Gata6 (64). However, Nanog can also activate the genes necessary for self-renewal such as Rexl. Nanog is highly expressed in pluripotent cells and its expression is down-regulated during differentiation. High expression of Nanog has been documented in many types of carcinomas such as tumor of brain, colon, breast, gastric, liver, kidney, and lung. Importantly, the expression of Nanog in certain tumors have provided positive correlation with treatment failure and poor prognosis of patients. Moreover, up-regulation of Nanog expression promotes tumorigenicity. These demonstrated that Nanog is associated with tumor progression, resistance to chemo/radiotherapy, and disease relapse (65). Nanog can be phosphorylated at four Ser/Thr-Pro motifs. These phosphorylation sites suppress the ubiquitination of Nanog and enhance its stability by promoting the interaction between Nanog and the prolyl isomerase Pin1 (66).

\section{CSC and Lung Cancer Metastasis}

Metastasis is a process comprising several steps where cancer cells disseminate form their original tumor to generate new tumors at distant parts (67). Like in other types of malignant human cancers, metastasis in lung cancer is considered as a key determining factor of prognosis of patients (68). Lung cancers are frequently diagnosed in metastatic stages (stage IV or more advance stages) at the time of first diagnosis (69). To successfully metastasize, the cancer cells encompass many biological processes including increased motility, induction of epithelial-mesenchymal transition (EMT), intravasation, survival in the blood or lymphatic circulations, extravasation, mesenchymalepithelial transition (MET), and ability to form new tumor (tumorigenesis) (70). A rare population (less than 1\%) of cancer cells could succeed in metastasizing. Several natural compounds have been tested for their possible role in preventing cancer cell dissemination as explained in our previous work (71). 


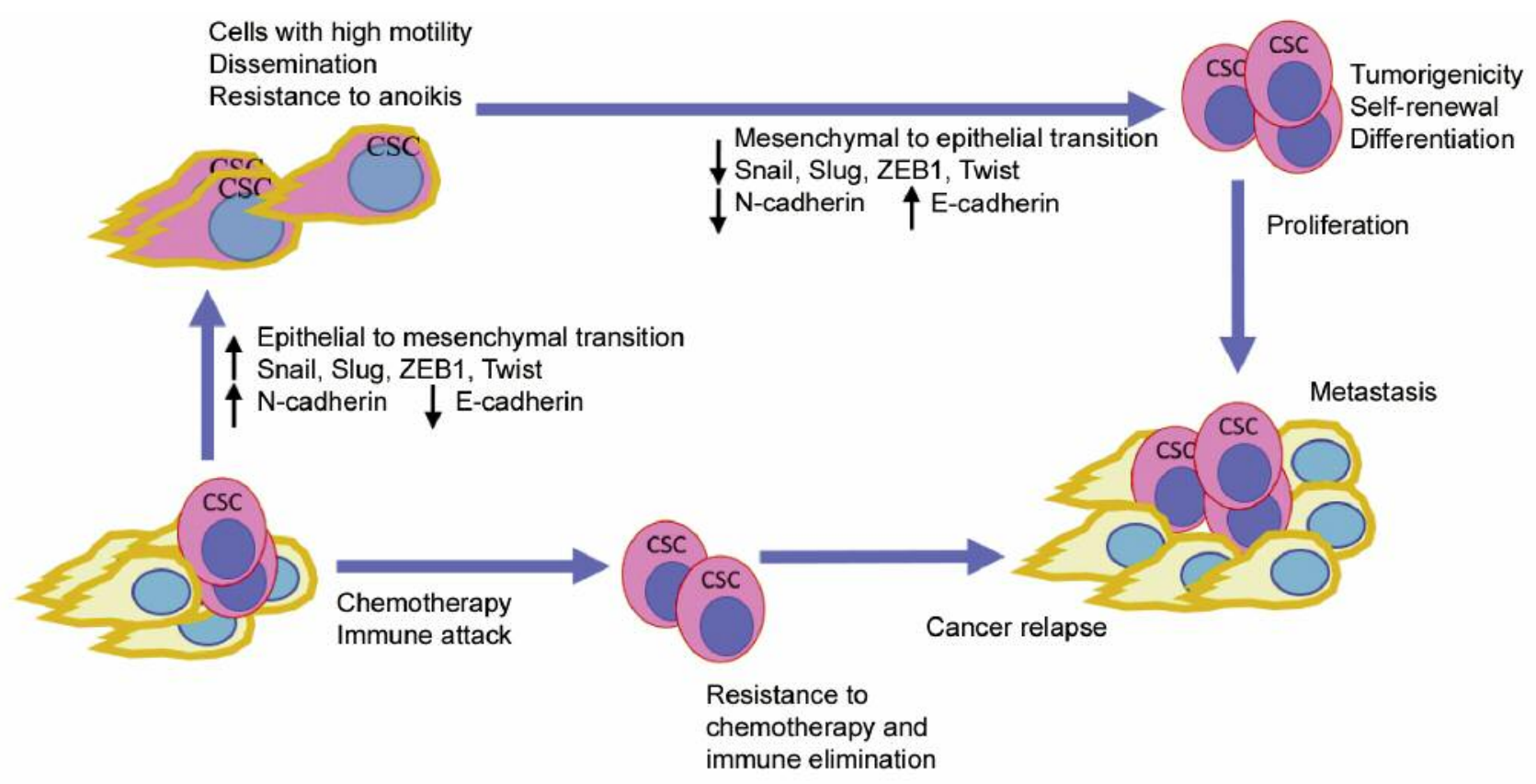

Figure 1. Schematic figure of cancer stem cell in implication to metastasis, chemotherapeutic resistance, epithelial to mesenchymal transition, and cancer relapse.

The process of cancer cell transition from epithelium-like cells to mesenchymal-like cells has been shown to be implicated in several behaviors of normal as well as cancerous cells (72). Epithelial to mesenchymal transition (EMT) is an essential process of the cancer cell to metastasize as it provides many important capabilities including ability to survive in detached conditions (anoikis resistance), increased invasion, and enhanced cell motility (73). It has been identified that the EMT in cancer cells involves several pleiotropic transcriptional factors, such as Snail (74), Slug (75), Zeb1 (76), Bmi-1 (77), and deltaEF1 (78). Such transcription factors enable EMT cells to disrupt epithelial adhesion, and cell to cell interaction (79). The EMT cells will then detach, leave the primary tumor mass, migrate, and invade into the circulation (80). It is known that EMT in cancer cells is relatively transient. Importantly, at the final step of cell dissemination when the cancer cells have reached the site of new establishment, the conversion of EMT named mesenchymal to epithelial transition (MET) is required to ensure stable cell interaction and adhesion to the surrounding new microenvironment (81). Therefore, the dynamic drive of EMT-MET processes is considered as a critical capability of cancer cells to metastasize (82).

After cancer cells have reached the site of metastasis, the tumorigenic potential, the unique property found in CSCs, of the cells is required for the establishment of new tumor $(83,84)$. These contexts have suggested the involvement of EMT and $\mathrm{CSC}$ in the process of metastasis. Even though the clear picture of how EMT relates to CSC is not yet verified, recent evidence has linked EMT to CSCs (85). EMT related transcription factors or inducers such as Epidermal Growth Factor (EGF), Transforming Growth Factor $\beta$ (TGF- $\beta$ ), Hepatocyte Growth Factor (HGF), Wnt/ $\beta$-catenin, Hedgehog, Notch pathways, are essential for CSCs $(86,87)$. Certain studies have pointed out that induction of EMT mediated by EMT inducers in fully differentiated epithelial cells can trigger CSC-like phenotypes including increased CD44, decreased CD24, and increased stem cell phenotypic markers $(85,88,89)$. Furthermore, the decrease in E-cadherin and increase in MMP-2, an indicator of EMT, were found to be critical for CSCs to metastasize (90).

In conclusion, evidence has pointed out that the key players of metastasis are the cell possessing ability of CSC to generate new tumor, increased motility, and EMT-MET transition. It has been assumed that metastasis-initiating cells are overlapping with CSCs to some degree. In addition, genetic evaluation of CSCs revealed their relevance in tumor recurrence and metastases, supporting the conclusion that CSCs may be metastatic precursors. The involvement of CSC in lung cancer metastasis, EMT-MET, and cancer relapse is presented in Figure 1.

\section{Natural Product Targeting Lung Cancer Stem Cells}

Natural products have been a rich source of novel lead compounds which may be useful for anti-cancer approaches. Here we summarized the discovered natural product-derived compounds (Table II) that have been demonstrated to influence 
Table II. Natural products targeting lung cancer stem cells and related mechanism.

\begin{tabular}{|c|c|c|c|c|}
\hline Compounds & Structure & Source & Proteins/signals & References \\
\hline Curcumin & & Curcuma longa & $\begin{array}{l}\text { DNA damage, } \\
\text { DNA repair, } \\
\text { JAK2/STAT3/Wnt } \\
\beta \text {-catenin, Sonic } \\
\text { Hedgehog } \\
\text { CD133, CD44, } \\
\text { ALDHA1, Nanog, } \\
\text { Oct4 }\end{array}$ & $(105,106)$ \\
\hline Gigantol & & Dendrobium draconis & $\begin{array}{l}\text { AKT, CD133, } \\
\text { ALDH1A1 }\end{array}$ & (114) \\
\hline Chrysotoxine & & Dendrobium pulchellum & $\begin{array}{l}\text { Src-AKT-Sox2, } \\
\text { CD133, CD } 44 \text {, } \\
\text { ABCG2, } \\
\text { ALDH1A1 }\end{array}$ & (116) \\
\hline Vanillin & & Vamilla planifolia & $\begin{array}{l}\text { AKT-proteasomal } \\
\text { degradation, } \\
\text { CD133, } \\
\text { ALDH1A1,Oct4, } \\
\text { Nanog }\end{array}$ & (121) \\
\hline Silibinin & & Silybum mariamum & ALDH activity & (123) \\
\hline Parthenolide & & Tamacetum parthenium & $\begin{array}{l}\text { ER stress, } \\
\text { Apoptosis, ATF4, } \\
\text { DDIT3, PMAIP }\end{array}$ & (129) \\
\hline Renieramycin M & & Xestospongia sp. & $\begin{array}{l}\text { CD133, CD44, } \\
\text { ALDH1A1 }\end{array}$ & (131) \\
\hline Salinomycin & & Streptomyces albus & $\begin{array}{l}\text { OCT-4, Nanog, } \\
\text { Sox2 }\end{array}$ & (134) \\
\hline
\end{tabular}


key CSC signaling pathways such as WNT/ $\beta$-catenin, Hedgehog, Notch and PI3K/AKT/mTOR pathways (91-93).

Curcumin, a yellow polyphenol, is a key compound derived from the rhizome of Turmeric (Curcuma longa) belonging to the ginger family (Zingiberaceae) (94). Previous studies have revealed the promising activities of curcumin against various kinds of cancer. Curcumin is able to suppress cancer signaling pathways, inhibit metastasis and angiogenesis, induce apoptosis, and sensitize tumor cells to cancer therapies (95-98). Several studies have suggested that curcumin can target CSCs in a variety of human cancer types (99-102) including lung cancer (103). Curcumin can diminish the self-renewal capacity of lung CSCs by inducing DNA damage or suppressing DNA repair mechanisms. Sheefa et al., studied the effect of curcumin on circulating CSCs isolated by sphere formation assay and observed a significant inhibition of sphere formation (104). Moreover, the result from single cell gel electrophoresis assay showed that $95.47 \pm 0.72 \%$ of DNA material was present in comet tail (104). Wu et al., reported that curcumin disturbed JAK2/STAT3 signaling pathway resulting in the reduction of tumor sphere growth of H460 lung cancer cells in vitro and in vivo (105). Curcumin has also been reported to reduce CSC marker (CD133, CD44, ALDHA1, Nanog and Oct4) expression, inhibit proliferation and induce apoptosis via down-regulation of WNT/ $\beta$-catenin and Sonic Hedgehog pathways in A549 and H1299 cells (106). Furthermore, curcumin is an attractive candidate for combination therapy because curcumin can target CSCs which are responsible for cancer recurrence and therapy resistance. Baharuddin et al., combined curcumin with low dose cisplatin $(3 \mu \mathrm{M})$ and found that curcumin increased the sensitivity of the highly migratory CD166+/EpCAM+ CSC subpopulation in the A549 and H2170 cells to cisplatin-induced apoptosis and inhibited migration (107).

Many studies have revealed that natural products isolated from Dendrobium species possess anticancer properties including anti-proliferation, anti-migration, anti-metastasis, and apoptotic induction in lung cancer (108-110). Gigantol, a bibenzyl phenolic compound derived from several medicinal orchids, has been shown to inhibit proliferation, migration, EMT and CSC phenotype in lung cancer cells (111-114). At non-toxic doses (below $20 \mu \mathrm{M}$ ), gigantol isolated from Dendrobium draconis could suppress tumor spheroid formation and decrease lung CSC marker proteins, including CD133 and ALDH1A1, in non-small-cell lung cancer NCI-H460 cells (112). Additionally, gigantol inhibited cancer stem cell-like phenotypes through down-regulation of AKT signaling pathway which lead to reduced levels of Oct4 and Nanog (114). Chrysotoxine, a bibenzyl compound isolated from stems of Dendrobium pulchellum, has been reported to sensitize anoikis and inhibit metastasis of lung cancer cells in an anchorage-independent fashion (115).
Bhummaphan et al. investigated the suppressive effects of chrysotoxine on CSC-rich populations of H460 and H23 cells and primary CSCs in three-dimensional (3D) culture and showed that non-toxic doses $(\leq 20 \mu \mathrm{M})$ of chrysotoxine inhibited CSC-like phenotypes and decreased CSC markers CD133, CD44, ABCG2 and ALDH1A1 which were mediated through a Src-AKT-Sox2-dependent mechanism (116).

Vanillin, a 4-hydroxy-3-methoxybenzaldehyde isolated from the seed of Vanilla planifolia, is widely used as a flavoring agent in food and cosmetics (117). Vanillin inhibited cell migration, lamellipodia formation and angiogenesis and induced apoptosis in many cancer types including lung cancer (117-120). Non-toxic doses (below $100 \mu \mathrm{M})$ of vanillin could inhibit spheroid and colony formation, major hallmarks of the cancer stemness, and reduce the CSC markers CD133 and ALDH1A1 and the related transcription factors, Oct4 and Nanog in $\mathrm{H} 460$ cells through the reduction of AKT and downstream CSC transcription factors (121).

Silibinin is a natural polyphenolic flavonoid derived from milk thistle seed (Silybum marianum) which has the ability to diminish many cancer types including lung cancer (122). To determine the suppressive effect of silibinin on lung cancer stem cells, Corominas-Faja et al. developed erlotinibrefractory cells (PC-9/Erl-R cells) by growing NSCLC PC9 cells expressing the $E G F R$ exon 19 deletion in routine culture medium containing a high dose of erlotinib $(1 \mu \mathrm{M})$ (123). The results from flow cytometry and the ALDEFLUOR $^{\circledR}$ reagent showed that silibinin reduced aldehyde dehydrogenase (ALDH)-expressing CSC-like cells in erlotinib-refractory cell populations and inhibited lung cancer spheres formation in a dose-dependent manner.

Isoflavone VF166, a derivative of soy isoflavone daidzein, can inhibit growth of various cancers including lung cancer. VF166 could suppress cell adhesion, migration and invasion of NSCLC in vitro. Moreover, the results from real time RTPCR revealed that treatment with VF166 up- and downregulated various genes including $D K K 1, K L F 4, M U C 1$, ErbB2, PTCH1 and SMO in NSCLC cells involved in the regulation of invasion associated signaling pathways such as WNT/ $\beta$-catenin, Hedgehog, STAT3, and SPARC (124).

Parthenolide, a natural sesquiterpene lactone isolated from the shoots of feverfew (Tanacetum parthenium), has anticancer effects on cancer cells and cancer stem cells from various types of cancer including lung cancer (125-128). Parthenolide has been shown to selectively kill cancer stemlike cells via ER stress and apoptosis signaling pathway in A549/shCDH1 cells in which CDH1/E-cadherin was knocked down with shRNA. Its underlying mechanisms are up-regulation of activating transcription factor 4 (ATF4) and DNA damage-inducible transcript 3 (DDIT3) expression which lead to up-regulation of Poly (ADP-ribose) polymerase-1 (PMAIP1) expression (129). 
Renieramycin M (RM) isolated from the blue sponge Xestospongia sp. has been reported to have anti-invasion, anti-migration, and apoptosis-inducing activities in lung cancer cells (130). RM treatment at non-toxic concentrations reduced significantly colony and spheroid formation of H460 cells. Furthermore, RM can also down-regulate the CSC markers CD133, CD44 and ALDH1A1 of CSC-enriched H460 cells (131).

Salinomycin is polyether ionophore antibiotic derived from Streptomyces albus (132). Salinomycin showed time- and dosedependent cytotoxic activity evaluated by sulforhodamine B and colony formation assay in LNM35 and A549 lung cancer cells (133). Treatment with salinomycin for $24 \mathrm{~h}$ has been shown to significantly inhibit the tumor sphere formation using flow cytometry and reduce stem cell markers OCT-4, NANOG and SOX2 expression by real-time RT-PCR analysis in ALDH A549 lung cells (134). Zhang et al. developed salinomycinnanoparticles (salinomycin-NPs) and gefitinib-nanoparticles (gefitinib-NPs) by the emulsion/solvent evaporation approach to kill both lung CSCs and lung cancer A549 and A431 cells (135). Both salinomycin and salinomycin-NPs could selectively target CD133 positive CSCs and reduce tumor sphere formation in lung cells, while gefitinib and gefitinibNPs preferably target lung cancer cells. Consistent with their in vitro results, salinomycin or salinomycin-NPs decreased CSC population in the tumors from nude mice bearing A431 xenografts. Furthermore, combination of Salinomycin-NPs and gefitinib-NPs has a more efficient suppressive effect on tumor growth than the combination of salinomycin and gefitinib or single salinomycin-NPs or gefitinib-NPs.

\section{Acknowledgements}

This research is supported by Ratchadapisek Somphot Fund for Postdoctoral Fellowship, Chulalongkorn University and grants from the Thailand Research Fund (RSA6180036).

\section{References}

1 Ferlay J, Soerjomataram I, Dikshit R, Eser S, Mathers C, Rebelo M, Parkin DM, Forman D and Bray F: Cancer incidence and mortality worldwide: sources, methods and major patterns in GLOBOCAN 2012. Int J Cancer 136: E359-386, 2015.

2 Beasley MB, Brambilla E and Travis WD: The 2004 World Health Organization classification of lung tumors. Semin Roentgenol 40: 90-97, 2005.

3 Dela Cruz CS, Tanoue LT and Matthay RA: Lung cancer: Epidemiology, etiology, and prevention. Clin Chest Med 32: 605-644, 2011.

4 Field RW and Withers BL: Occupational and environmental causes of lung cancer. Clin Chest Med 33: 681-703, 2012.

5 Loomis D, Grosse Y, Lauby-Secretan B, Ghissassi FE, Bouvard V, Benbrahim-Tallaa L, Guha N, Baan R, Mattock H and Straif $\mathrm{K}$ : The carcinogenicity of outdoor air pollution. Lancet Oncol 14: 1262-1263, 2013
6 Bonnet D and Dick JE: Human acute myeloid leukemia is organized as a hierarchy that originates from a primitive hematopoietic cell. Nat Med 3: 730-737, 1997.

7 Pardal R, Clarke MF and Morrison SJ: Applying the principles of stem-cell biology to cancer. Nat Rev Cancer 3: 895-902, 2003.

8 Koren E and Fuchs Y: The bad seed: Cancer stem cells in tumor development and resistance. Drug Resist Updat Rev Comment Antimicrob Anticancer Chemother 28: 1-12, 2016.

9 Adorno-Cruz V, Kibria G, Liu X, Doherty M, Junk DJ, Guan D, Hubert C, Venere M, Mulkearns-Hubert E, Sinyuk M, Alvarado A, Caplan AI, Rich J, Gerson SL, Lathia J and Liu H: Cancer stem cells: Targeting the roots of cancer, seeds of metastasis, and sources of therapy resistance. Cancer Res 75: 924-929, 2015.

10 Nassar D and Blanpain C: Cancer stem cells: Basic concepts and therapeutic implications. Annu Rev Pathol Mech Dis 11: 47-76, 2016.

11 Friedmann-Morvinski D and Verma IM: Dedifferentiation and reprogramming: origins of cancer stem cells. EMBO Rep 15: 244-253, 2014.

12 Lobo NA, Shimono Y, Qian D and Clarke MF: The biology of cancer stem cells. Annu Rev Cell Dev Biol 23: 675-699, 2007.

13 Chang JC: Cancer stem cells: Role in tumor growth, recurrence, metastasis, and treatment resistance. Medicine (Baltimore) 95: S20-25, 2016.

14 Donnenberg VS, Landreneau RJ and Donnenberg AD: Tumorigenic stem and progenitor cells: implications for the therapeutic index of anti-cancer agents. J Control Release Off J Control Release Soc 122: 385-391, 2007

15 Lapidot T, Sirard C, Vormoor J, Murdoch B, Hoang T, CaceresCortes J, Minden M, Paterson B, Caligiuri MA and Dick JE: A cell initiating human acute myeloid leukaemia after transplantation into SCID mice. Nature 367: 645-648, 1994.

16 Tirino V, Desiderio V, Paino F, De Rosa A, Papaccio F, La Noce M, Laino L, De Francesco F and Papaccio G: Cancer stem cells in solid tumors: An overview and new approaches for their isolation and characterization. FASEB J Off Publ Fed Am Soc Exp Biol 27: 13-24, 2013

17 Wang P, Wan W, Xiong S-L, Feng H and Wu N: Cancer stemlike cells can be induced through dedifferentiation under hypoxic conditions in glioma, hepatoma and lung cancer. Cell Death Discov 3: 16105, 2017.

18 Yongsanguanchai N, Pongrakhananon V, Mutirangura A, Rojanasakul $\mathrm{Y}$ and Chanvorachote $\mathrm{P}$ : Nitric oxide induces cancer stem cell-like phenotypes in human lung cancer cells. Am J Physiol Cell Physiol 308: C89-100, 2015.

19 Carnero A and Lleonart M: The hypoxic microenvironment: A determinant of cancer stem cell evolution. Cell 1: 96-105, 2016.

20 Krishnamurthy S, Warner KA, Dong Z, Imai A, Nör C, Ward BB, Helman JI, Taichman RS, Bellile EL, McCauley LK, Polverini PJ, Prince ME, Wicha MS and Nör JE: Endothelial interleukin6 defines the tumorigenic potential of primary human cancer stem cells. Stem Cells Dayt Ohio 32: 2845-2857, 2014.

21 Gadepalli VS, Deb SP, Deb S and Rao RR: Lung cancer stem cells, p53 mutations and MDM2. Subcell Biochem 85: 359-370, 2014.

22 Ashkenazi R, Gentry SN and Jackson TL: Pathways to tumorigenesis--modeling mutation acquisition in stem cells and their progeny. Neoplasia NY N 10: 1170-1182, 2008.

23 Tang DG: Understanding cancer stem cell heterogeneity and plasticity. Cell Res 22: 457-472, 2012. 
24 Cioffi M, D'Alterio C, Camerlingo R, Tirino V, Consales C, Riccio A, Ieranò C, Cecere SC, Losito NS, Greggi S, Pignata $S$, Pirozzi G and Scala S: Identification of a distinct population of CD133(+)CXCR4(+) cancer stem cells in ovarian cancer. Sci Rep 5: 10357, 2015.

25 Li Z: CD133: A stem cell biomarker and beyond. Exp Hematol Oncol 2: 17, 2013.26Miraglia S, Godfrey W, Yin AH, Atkins K, Warnke R, Holden JT, Bray RA, Waller EK and Buck DW: A novel five-transmembrane hematopoietic stem cell antigen: isolation, characterization, and molecular cloning. Blood 90: 5013-5021, 1997.

27 Yin AH, Miraglia S, Zanjani ED, Almeida-Porada G, Ogawa M, Leary AG, Olweus J, Kearney J and Buck DW: AC133, a novel marker for human hematopoietic stem and progenitor cells. Blood 90: 5002-5012, 1997.

28 Beier D, Hau P, Proescholdt M, Lohmeier A, Wischhusen J, Oefner PJ, Aigner L, Brawanski A, Bogdahn U and Beier CP: CD133(+) and CD133(-) glioblastoma-derived cancer stem cells show differential growth characteristics and molecular profiles. Cancer Res 67: 4010-4015, 2007.

29 Qu H, Li R, Liu Z, Zhang J and Luo R: Prognostic value of cancer stem cell marker CD133 expression in non-small cell lung cancer: a systematic review. Int J Clin Exp Pathol 6: 2644-2650, 2013.

30 Li B, McCrudden CM, Yuen HF, Xi X, Lyu P, Chan KW, Zhang SD and Kwok HF: CD133 in brain tumor: the prognostic factor. Oncotarget 8: 11144-11159, 2017.

31 Kazama S, Kishikawa J, Kiyomatsu T, Kawai K, Nozawa H, Ishihara $\mathrm{S}$ and Watanabe T: Expression of the stem cell marker CD133 is related to tumor development in colorectal carcinogenesis. Asian J Surg 41: 274-278, 2018.

32 Ferrand A, Sandrin MS, Shulkes A and Baldwin GS: Expression of gastrin precursors by CD133-positive colorectal cancer cells is crucial for tumour growth. Biochim Biophys Acta BBA - Mol Cell Res 1793: 477-488, 2009.

33 Zakaria N, Yusoff NM, Zakaria Z, Lim MN, Baharuddin PJN, Fakiruddin KS and Yahaya B: Human non-small cell lung cancer expresses putative cancer stem cell markers and exhibits the transcriptomic profile of multipotent cells. BMC Cancer 15: 84, 2015.

34 Immervoll H, Hoem D, Sakariassen PØ, Steffensen OJ and Molven A: Expression of the "stem cell marker" CD133 in pancreas and pancreatic ductal adenocarcinomas. BMC Cancer 8: 48, 2008.

35 Yin S, Li J, Hu C, Chen X, Yao M, Yan M, Jiang G, Ge C, Xie $\mathrm{H}$, Wan D, Yang S, Zheng S and Gu J: CD133 positive hepatocellular carcinoma cells possess high capacity for tumorigenicity. Int J Cancer 120: 1444-1450, 2007.

36 Pellacani D, Oldridge EE, Collins AT and Maitland NJ: Prominin-1 (CD133) expression in the prostate and prostate cancer: A marker for quiescent stem cells. Adv Exp Med Biol 777: 167-184, 2013.

37 Zhang M, Song T, Yang L, Chen R, Wu L, Yang Z and Fang J: Nestin and CD133: valuable stem cell-specific markers for determining clinical outcome of glioma patients. J Exp Clin Cancer Res CR 27: 85, 2008.

38 Wang B-B, Li Z-J, Zhang F-F, Hou H-T, Yu J-K and Li F: Clinical significance of stem cell marker CD133 expression in colorectal cancer. Histol Histopathol 31: 299-306, 2016.

39 Costa WH da, Rocha RM, Cunha IW da, Fonseca FP da, Guimaraes GC and Zequi S de C: CD133 immunohistochemical expression predicts progression and cancer-related death in renal cell carcinoma. World J Urol 30: 553-558, 2012.

40 Sarvi S, Mackinnon AC, Avlonitis N, Bradley M, Rintoul RC, Rassl DM, Wang W, Forbes SJ, Gregory CD and Sethi T: $\mathrm{CD} 133+$ cancer stem-like cells in small cell lung cancer are highly tumorigenic and chemoresistant but sensitive to a novel neuropeptide antagonist. Cancer Res 74: 1554-1565, 2014.

41 Ponta H, Sherman L and Herrlich PA: CD44: from adhesion molecules to signalling regulators. Nat Rev Mol Cell Biol 4: 33-45, 2003

42 Herishanu Y, Gibellini F, Njuguna N, Hazan-Halevy I, Keyvanfar K, Lee E, Wilson W and Wiestner A: CD44 signaling via $\mathrm{PI} 3 \mathrm{~K} / \mathrm{AKT}$ and MAPK/ERK pathways protects CLL cells from spontaneous and drug induced apoptosis through MCL-1. Leuk Lymphoma 52: 1758-1769, 2011.

43 Leung EL-H, Fiscus RR, Tung JW, Tin VP-C, Cheng LC, Sihoe AD-L, Fink LM, Ma Y and Wong MP: Non-small cell lung cancer cells expressing CD44 are enriched for stem cell-like properties. PLOS ONE 5: e14062, 2010.

44 Raha D, Wilson TR, Peng J, Peterson D, Yue P, Evangelista M, Wilson C, Merchant M and Settleman J: The cancer stem cell marker aldehyde dehydrogenase is required to maintain a drugtolerant tumor cell subpopulation. Cancer Res 74: 3579-3590, 2014.

45 Ma I and Allan AL: The role of human aldehyde dehydrogenase in normal and cancer stem cells. Stem Cell Rev 7: 292-306, 2011.

46 Jiang F, Qiu Q, Khanna A, Todd NW, Deepak J, Xing L, Wang H, Liu Z, Su Y, Stass SA and Katz RL: Aldehyde dehydrogenase 1 is a tumor stem cell-associated marker in lung cancer. Mol Cancer Res MCR 7: 330-338, 2009.

47 Liu J, Xiao Z, Wong SK-M, Tin VP-C, Ho K-Y, Wang J, Sham $\mathrm{M}-\mathrm{H}$ and Wong MP: Lung cancer tumorigenicity and drug resistance are maintained through $\mathrm{ALDH}(\mathrm{hi}) \mathrm{CD} 44(\mathrm{hi})$ tumor initiating cells. Oncotarget 4: 1698-1711, 2013.

48 Kahlert C, Gaitzsch E, Steinert G, Mogler C, Herpel E, Hoffmeister M, Jansen L, Benner A, Brenner H, Chang-Claude J, Rahbari N, Schmidt T, Klupp F, Grabe N, Lahrmann B, Koch M, Halama N, Büchler M and Weitz J: Expression analysis of aldehyde dehydrogenase 1A1 (ALDH1A1) in colon and rectal cancer in association with prognosis and response to chemotherapy. Ann Surg Oncol 19: 4193-4201, 2012.

49 Ding X, Wu J and Jiang C: ABCG2: A potential marker of stem cells and novel target in stem cell and cancer therapy. Life Sci 86: 631-637, 2010.

50 Naylor CS, Jaworska E, Branson K, Embleton MJ and Chopra $\mathrm{R}$ : Side population/ABCG2-positive cells represent a heterogeneous group of haemopoietic cells: Implications for the use of adult stem cells in transplantation and plasticity protocols. Bone Marrow Transplant 35: 353-360, 2005.

51 Fatima S, Zhou S and Sorrentino BP: Abcg2 expression marks tissue-specific stem cells in multiple organs in a mouse progeny tracking model. Stem Cells Dayt Ohio 30: 210-221, 2012.

52 Wang H, Luo F, Zhu Z, Xu Z, Huang X, Ma R, He H, Zhu Y, Shao $\mathrm{K}$ and Zhao J: ABCG2 is a potential prognostic marker of overall survival in patients with clear cell renal cell carcinoma. BMC Cancer 17: 222, 2017.

53 Liang S-C, Yang C-Y, Tseng J-Y, Wang H-L, Tung C-Y, Liu HW, Chen C-Y, Yeh Y-C, Chou T-Y, Yang M-H, Whang-Peng J and Lin C-H: ABCG2 localizes to the nucleus and modulates CDH1 expression in lung cancer cells. Neoplasia NY N 17: 265-278, 2015. 
54 Pan GJ, Chang ZY, Schöler HR and Pei D: Stem cell pluripotency and transcription factor Oct4. Cell Res 12: 321329, 2002.

55 Matoba R, Niwa H, Masui S, Ohtsuka S, Carter MG, Sharov AA and Ko MSH: Dissecting Oct3/4-regulated gene networks in embryonic stem cells by expression profiling. PLOS ONE 1 : e26, 2006.

56 Hayashi H, Arao T, Togashi Y, Kato H, Fujita Y, De Velasco MA, Kimura H, Matsumoto K, Tanaka K, Okamoto I, Ito A, Yamada Y, Nakagawa K and Nishio K: The OCT4 pseudogene POU5F1B is amplified and promotes an aggressive phenotype in gastric cancer. Oncogene 34: 199-208, 2015.

57 Kumar SM, Liu S, Lu H, Zhang H, Zhang PJ, Gimotty PA, Guerra $\mathrm{M}$, Guo $\mathrm{W}$ and $\mathrm{Xu} \mathrm{X}$ : Acquired cancer stem cell phenotypes through Oct4-mediated dedifferentiation. Oncogene 31: 4898-4911, 2012.

58 Zhao Q-W, Zhou Y-W, Li W-X, Kang B, Zhang X-Q, Yang Y, Cheng J, Yin S-Y, Tong Y, He J-Q, Yao H-P, Zheng M and Wang Y-J: Akt-mediated phosphorylation of Oct4 is associated with the proliferation of stem-like cancer cells. Oncol Rep 33: 1621-1629, 2015.

59 Cai N, Li M, Qu J, Liu G-H and Izpisua Belmonte JC: Posttranslational modulation of pluripotency. J Mol Cell Biol 4: 262-265, 2012.

60 Liao B and Jin Y: Wwp2 mediates Oct4 ubiquitination and its own auto-ubiquitination in a dosage-dependent manner. Cell Res 20: 332-344, 2010.

61 Sarkar A and Hochedlinger K: The sox family of transcription factors: versatile regulators of stem and progenitor cell fate. Cell Stem Cell 12: 15-30, 2013.

62 Ellis P, Fagan BM, Magness ST, Hutton S, Taranova O, Hayashi S, McMahon A, Rao M and Pevny L: SOX2, a persistent marker for multipotential neural stem cells derived from embryonic stem cells, the embryo or the adult. Dev Neurosci 26: 148-165, 2004

63 Weina $\mathrm{K}$ and Utikal J: SOX2 and cancer: Current research and its implications in the clinic. Clin Transl Med 3: 19, 2014.

64 Hyslop L, Stojkovic M, Armstrong L, Walter T, Stojkovic P, Przyborski S, Herbert M, Murdoch A, Strachan T and Lako M: Downregulation of NANOG induces differentiation of human embryonic stem cells to extraembryonic lineages. Stem Cells 23: 1035-1043, 2015

65 Gong S, Li Q, Jeter CR, Fan Q, Tang DG and Liu B: Regulation of NANOG in cancer cells. Mol Carcinog 54: 679687,2015

66 Moretto-Zita M, Jin H, Shen Z, Zhao T, Briggs SP and Xu Y: Phosphorylation stabilizes Nanog by promoting its interaction with Pin1. Proc Natl Acad Sci USA 107: 13312-13317, 2010.

67 Lambert AW, Pattabiraman DR and Weinberg RA: Emerging biological principles of metastasis. Cell 168: 670-691, 2017.

68 Popper HH: Progression and metastasis of lung cancer. Cancer Metastasis Rev 35: 75-91, 2016.

69 Ellis PM and Vandermeer R: Delays in the diagnosis of lung cancer. J Thorac Dis 3: 183-188, 2011.

70 Valastyan S and Weinberg RA: Tumor metastasis: Molecular insights and evolving paradigms. Cell 147: 275-292, 2011.

71 Chanvorachote P, Chamni S, Ninsontia C and Phiboonchaiyanan PP: Potential anti-metastasis natural compounds for lung cancer. Anticancer Res 36: 5707-5717, 2016.
72 Micalizzi DS, Farabaugh SM and Ford HL: Epithelialmesenchymal transition in cancer: Parallels between normal development and tumor progression. J Mammary Gland Biol Neoplasia 15: 117-134, 2010.

73 Nieto MA: Epithelial-mesenchymal transitions in development and disease: Old views and new perspectives. Int J Dev Biol 53: 1541-1547, 2009.

74 Cano A, Pérez-Moreno MA, Rodrigo I, Locascio A, Blanco MJ, Barrio MG del, Portillo F and Nieto MA: The transcription factor Snail controls epithelial-mesenchymal transitions by repressing E-cadherin expression. Nat Cell Biol 2: 76-83, 2000.

75 Bolós V, Peinado H, Pérez-Moreno MA, Fraga MF, Esteller M and Cano A: The transcription factor Slug represses E-cadherin expression and induces epithelial to mesenchymal transitions: a comparison with Snail and E47 repressors. J Cell Sci 116: 499-511, 2003.

76 Liu Y, El-Naggar S, Darling DS, Higashi Y and Dean DC: Zeb1 links epithelial-mesenchymal transition and cellular senescence. Development 135: 579-588, 2008.

77 Song L-B, Li J, Liao W-T, Feng Y, Yu C-P, Hu L-J, Kong Q-L, Xu L-H, Zhang X, Liu W-L, Li M-Z, Zhang L, Kang T-B, Fu L-W, Huang W-L, Xia Y-F, Tsao SW, Li M, Band V, Band H, Shi Q-H, Zeng Y-X and Zeng M-S: The polycomb group protein Bmi-1 represses the tumor suppressor PTEN and induces epithelial-mesenchymal transition in human nasopharyngeal epithelial cells. J Clin Invest 119: 3626-3636, 2009.

78 Eger A, Aigner K, Sonderegger S, Dampier B, Oehler S, Schreiber M, Berx G, Cano A, Beug $\mathrm{H}$ and Foisner R: DeltaEF1 is a transcriptional repressor of E-cadherin and regulates epithelial plasticity in breast cancer cells. Oncogene 24: 2375-2385, 2005.

79 Lamouille S, Xu J and Derynck R: Molecular mechanisms of epithelial-mesenchymal transition. Nat Rev Mol Cell Biol 15: 178-196, 2014.

80 Yilmaz $\mathrm{M}$ and Christofori G: EMT, the cytoskeleton, and cancer cell invasion. Cancer Metastasis Rev 28: 15-33, 2009.

81 Jolly MK, Ware KE, Gilja S, Somarelli JA and Levine H: EMT and MET: necessary or permissive for metastasis? Mol Oncol 11: 755-769, 2017.

82 Tsai JH, Donaher JL, Murphy DA, Chau S and Yang J: Spatiotemporal regulation of epithelial-mesenchymal transition is essential for squamous cell carcinoma metastasis. Cancer Cell 22: 725-736, 2012.

83 Shiozawa Y, Nie B, Pienta KJ, Morgan TM and Taichman RS: Cancer stem cells and their role in metastasis. Pharmacol Ther 138: 285-293, 2013.

84 LI S and LI Q: Cancer stem cells and tumor metastasis. Int J Oncol 44: 1806-1812, 2014.

85 Mani SA, Guo W, Liao M-J, Eaton EN, Ayyanan A, Zhou AY, Brooks M, Reinhard F, Zhang CC, Shipitsin M, Campbell LL, Polyak K, Brisken C, Yang J and Weinberg RA: The epithelialmesenchymal transition generates cells with properties of stem cells. Cell 133: 704-715, 2008.

86 Vermeulen L, Melo FDSE, Heijden M van der, Cameron K, Jong JH de, Borovski T, Tuynman JB, Todaro M, Merz C, Rodermond H, Sprick MR, Kemper K, Richel DJ, Stassi G and Medema JP: Wnt activity defines colon cancer stem cells and is regulated by the microenvironment. Nat Cell Biol 12: 468476, 2010. 
87 Moustakas A and Heldin C-H: Signaling networks guiding epithelial-mesenchymal transitions during embryogenesis and cancer progression. Cancer Sci 98: 1512-1520, 2007.

88 Battula VL, Evans KW, Hollier BG, Shi Y, Marini FC, Ayyanan A, Wang R, Brisken C, Guerra R, Andreeff M and Mani SA: Epithelial-mesenchymal transition-derived cells exhibit multilineage differentiation potential similar to mesenchymal stem cells. Stem Cells 28: 1435-1445, 2010.

89 Asiedu MK, Ingle JN, Behrens MD, Radisky DC and Knutson KL: TGF $\beta / T N F \alpha$-mediated epithelial-mesenchymal transition generates breast cancer stem cells with a claudin-low phenotype. Cancer Res 71: 4707-4719, 2011.

90 Yang L, Ping Y-F, Yu X, Qian F, Guo Z-J, Qian C, Cui Y-H and Bian X-W: Gastric cancer stem-like cells possess higher capability of invasion and metastasis in association with a mesenchymal transition phenotype. Cancer Lett 310: 46-52, 2011.

91 Moselhy J, Srinivasan S, Ankem MK and Damodaran C: Natural products that target cancer stem cells. Anticancer Res 35: 5773-5788, 2015.

92 Dandawate PR, Subramaniam D, Jensen RA and Anant S: Targeting cancer stem cells and signaling pathways by phytochemicals: Novel approach for breast cancer therapy. Semin Cancer Biol 40-41: 192-208, 2016.

93 Taylor WF and Jabbarzadeh E: The use of natural products to target cancer stem cells. Am J Cancer Res 7: 1588-1605, 2017.

94 Rauf A, Imran M, Orhan IE and Bawazeer S: Health perspectives of a bioactive compound curcumin: A review. Trends Food Sci Technol 74: 33-45, 2018.

95 Chanvorachote $\mathrm{P}$, Pongrakhananon V, Wannachaiyasit S, Luanpitpong S, Rojanasakul Y and Nimmannit U: Curcumin sensitizes lung cancer cells to cisplatin-induced apoptosis through superoxide anion-mediated Bcl-2 degradation. Cancer Invest 27: 624-635, 2009.

96 Pongrakhananon V, Nimmannit U, Luanpitpong S, Rojanasakul $\mathrm{Y}$ and Chanvorachote P: Curcumin sensitizes non-small cell lung cancer cell anoikis through reactive oxygen speciesmediated Bcl-2 downregulation. Apoptosis Int J Program Cell Death 15: 574-585, 2010.

97 Lin S-S, Lai K-C, Hsu S-C, Yang J-S, Kuo C-L, Lin J-P, Ma Y$\mathrm{S}, \mathrm{Wu} \mathrm{C}-\mathrm{C}$ and Chung J-G: Curcumin inhibits the migration and invasion of human A549 lung cancer cells through the inhibition of matrix metalloproteinase-2 and -9 and Vascular Endothelial Growth Factor (VEGF). Cancer Lett 285: 127-133, 2009.

98 Li Y and Zhang T: Targeting cancer stem cells by curcumin and clinical applications. Cancer Lett 346: 197-205, 2014.

99 Ramasamy TS, Ayob AZ, Myint HHL, Thiagarajah S and Amini F: Targeting colorectal cancer stem cells using curcumin and curcumin analogues: insights into the mechanism of the therapeutic efficacy. Cancer Cell Int 15: 96, 2015.

100 Zhang H, Yu T, Wen L, Wang H, Fei D and Jin C: Curcumin enhances the effectiveness of cisplatin by suppressing CD133+ cancer stem cells in laryngeal carcinoma treatment. Exp Ther Med 6: 1317-1321, 2013.

101 Zhou Q-M, Sun Y, Lu Y-Y, Zhang H, Chen Q-L and Su S-B: Curcumin reduces mitomycin $\mathrm{C}$ resistance in breast cancer stem cells by regulating Bcl-2 family-mediated apoptosis. Cancer Cell Int 17: 84, 2017.

102 Mukherjee S, Mazumdar M, Chakraborty S, Manna A, Saha S, Khan P, Bhattacharjee P, Guha D, Adhikary A, Mukhjerjee S and Das T: Curcumin inhibits breast cancer stem cell migration by amplifying the E-cadherin/ $\beta$-catenin negative feedback loop. Stem Cell Res Ther 5: 116, 2014.

103 Zakaria N, Satar NA, Abu Halim NH, Ngalim SH, Yusoff NM, Lin $\mathrm{J}$ and Yahaya BH: Targeting lung cancer stem cells: Research and clinical impacts. Front Oncol 7: 80, 2017.

104 Mirza S, Vasaiya A, Vora H, Jain N and Rawal R: Curcumin targets circulating cancer stem cells by inhibiting self-renewal efficacy in non-small cell lung carcinoma. Anticancer Agents Med Chem 17: 859-864, 2017.

$105 \mathrm{Wu}$ L, Guo L, Liang Y, Liu X, Jiang L and Wang L: Curcumin suppresses stem-like traits of lung cancer cells via inhibiting the JAK2/STAT3 signaling pathway. Oncol Rep 34: 3311-3317, 2015.

106 Zhu JY, Yang X, Chen Y, Jiang Y, Wang SJ, Li Y, Wang XQ, Meng Y, Zhu MM, Ma X,Huang C, Wu R, Xie CF, Li XT, Geng SS, Wu JS, Zhong CY and Han HY: Curcumin suppresses lung cancer stem cells via inhibiting $\mathrm{Wnt} / \beta$-catenin and sonic hedgehog pathways. Phytother Res 31: 680-688, 2017.

107 Baharuddin P, Satar N, Fakiruddin KS, Zakaria N, Lim MN, Yusoff NM, Zakaria Z and Yahaya BH: Curcumin improves the efficacy of cisplatin by targeting cancer stem-like cells through p21 and cyclin D1-mediated tumour cell inhibition in non-small cell lung cancer cell lines. Oncol Rep 35: 13-25, 2016.

108 Pinkhien T, Petpiroon N, Sritularak B and Chanvorachote P: Batatasin III inhibits migration of human lung cancer cells by suppressing epithelial to mesenchymal transition and FAK-AKT signals. Anticancer Res 37: 6281-6289, 2017.

109 Chaotham C, Pongrakhananon V, Sritularak B and Chanvorachote P: A bibenzyl from Dendrobium ellipsophyllum inhibits epithelial-to-mesenchymal transition and sensitizes lung cancer cells to anoikis. Anticancer Res 34: 1931-1938, 2014.

110 Hlosrichok A, Sumkhemthong S, Sritularak B, Chanvorachote P and Chaotham C: A bibenzyl from Dendrobium ellipsophyllum induces apoptosis in human lung cancer cells. J Nat Med 72: 615-625, 2018.

111 Unahabhokha T, Chanvorachote P, Sritularak B, Kitsongsermthon $\mathrm{J}$ and Pongrakhananon V: Gigantol inhibits epithelial to mesenchymal process in human lung cancer cells. Evid Based Complement Alternat Med 2016: 1-10, 2016.

112 Charoenrungruang S, Chanvorachote P, Sritularak B and Pongrakhananon V: Gigantol, a bibenzyl from Dendrobium draconis, inhibits the migratory behavior of non-small cell lung cancer cells. J Nat Prod 77: 1359-1366, 2014.

113 Klongkumnuankarn P, Busaranon K, Chanvorachote P, Sritularak B, Jongbunprasert V and Likhitwitayawuid K: Cytotoxic and antimigratory activities of phenolic compounds from Dendrobium brymerianum. Evid Based Complement Alternat Med 2015: 1-9, 2015.

114 Bhummaphan N and Chanvorachote P: Gigantol suppresses cancer stem cell-like phenotypes in lung cancer cells. Evid Based Complement Alternat Med 2015: 1-10, 2015.

115 Chanvorachote P, Kowitdamrong A, Ruanghirun T, Sritularak $\mathrm{B}$, Mungmee $\mathrm{C}$ and Likhitwitayawuid $\mathrm{K}$ : Anti-metastatic activities of bibenzyls from Dendrobium pulchellum. Nat Prod Commun 8: 115-118, 2013.

116 Bhummaphan N, Pongrakhananon V, Sritularak B and Chanvorachote P: Cancer stem cell suppressing activity of chrysotoxine, a bibenzyl from Dendrobium pulchellum. J Pharmacol Exp Ther 364: 332-346, 2017. 
117 Bezerra DP, Soares AKN, Sousa D and Pergentino D: Overview of the role of vanillin on redox status and cancer development. Oxid Med Cell Longev 2016: 1-9, 2016.

118 Lirdprapamongkol K, Kramb J-P, Suthiphongchai T, Surarit R, Srisomsap C, Dannhardt G and Svasti J: Vanillin suppresses metastatic potential of human cancer cells through PI3K inhibition and decreases angiogenesis in vivo. J Agric Food Chem 57: 3055-3063, 2009.

119 Lirdprapamongkol K, Sakurai H, Suzuki S, Koizumi K, Prangsaengtong O, Viriyaroj A, Ruchirawat S, Svasti J and Saiki I: Vanillin enhances TRAIL-induced apoptosis in cancer cells through inhibition of NF-kappaB activation. In Vivo 24: 501-506, 2010.

120 Lirdprapamongkol K, Sakurai H, Kawasaki N, Choo M-K, Saitoh Y, Aozuka Y, Singhirunnusorn P, Ruchirawat S, Svasti J and Saiki I: Vanillin suppresses in vitro invasion and in vivo metastasis of mouse breast cancer cells. Eur J Pharm Sci Off J Eur Fed Pharm Sci 25: 57-65, 2005.

121 Srinual S, Chanvorachote $\mathrm{P}$ and Pongrakhananon V: Suppression of cancer stem-like phenotypes in NCI-H460 lung cancer cells by vanillin through an Akt-dependent pathway. Int J Oncol 50: 1341-1351, 2017.

122 Zhu X-X, Ding Y-H, Wu Y, Qian L-Y, Zou H and He Q: Silibinin: A potential old drug for cancer therapy. Expert Rev Clin Pharmacol 18: 1-8, 2016.

123 Corominas-Faja B, Oliveras-Ferraros C, Cuyàs E, SeguraCarretero A, Joven J, Martin-Castillo B, Barrajón-Catalán E, Micol V, Bosch-Barrera J and Menendez JA: Stem cell-like ALDH(bright) cellular states in EGFR-mutant non-small cell lung cancer: a novel mechanism of acquired resistance to erlotinib targetable with the natural polyphenol silibinin. Cell Cycle Georget Tex 12: 3390-3404, 2013.

124 Schwarz Y, Bondar E, Shai AB, Kohen F and Starr A: Molecular mechanisms of inhibition of lung cancer stem cells invasion by a novel soy isoflavone VF166. Eur Respir J 48: PA2838, 2016.

125 Ghantous A, Sinjab A, Herceg Z and Darwiche N: Parthenolide: from plant shoots to cancer roots. Drug Discov Today 18: 894905, 2013.

126 Liao K, Xia B, Zhuang Q-Y, Hou M-J, Zhang Y-J, Luo B, Qiu Y, Gao Y-F, Li X-J, Chen H-F, Ling W-H, He C-Y, Huang Y-J, Lin Y-C and Lin Z-N: Parthenolide inhibits cancer stem-like side population of nasopharyngeal carcinoma cells via suppression of the NF-kB/COX-2 pathway. Theranostics 5: 302-321, 2015.
127 Guzman ML, Rossi RM, Karnischky L, Li X, Peterson DR, Howard DS and Jordan CT: The sesquiterpene lactone parthenolide induces apoptosis of human acute myelogenous leukemia stem and progenitor cells. Blood 105: 4163-4169, 2005.

128 Lin M, Bi H, Yan Y, Huang W, Zhang G, Zhang G, Tang S, Liu Y, Zhang L, Ma J and Zhang J: Parthenolide suppresses nonsmall cell lung cancer GLC-82 cells growth via BRaf/MAPK/Erk pathway. Oncotarget 8: 23436-23447, 2017.

129 Zhao X, Liu X and Su L: Parthenolide induces apoptosis via TNFRSF10B and PMAIP1 pathways in human lung cancer cells. J Exp Clin Cancer Res CR 33: 3, 2014.

130 Halim H, Chunhacha P, Suwanborirux K and Chanvorachote P: Anticancer and antimetastatic activities of renieramycin $\mathrm{M}$, a marine tetrahydroisoquinoline alkaloid, in human non-small cell lung cancer cells. Anticancer Res 31: 193-201, 2011.

131 Sirimangkalakitti N, Chamni S, Suwanborirux K and Chanvorachote P: Renieramycin $\mathrm{M}$ attenuates cancer stem celllike phenotypes in H460 lung cancer cells. Anticancer Res 37: 615-621, 2017.

132 Miyazaki Y, Shibuya M, Sugawara H, Kawaguchi O and Hirsoe C: Salinomycin, a new antibiotic. J Antibiot (Tokyo) 27: 814821, 1974.

133 Arafat K, Iratni R, Takahashi T, Parekh K, Al Dhaheri Y, Adrian TE and Attoub S: Inhibitory effects of salinomycin on cell survival, colony growth, migration, and invasion of human nonsmall cell lung cancer A549 and LNM35: Involvement of NAG-1. PLOS ONE 8: e66931, 2013.

134 Wang Y: Effects of salinomycin on cancer stem cell in human lung adenocarcinoma A549 cells. Med Chem Shariqah United Arab Emir 7: 106-111, 2011

135 Zhang Y, Zhang Q, Sun J, Liu H and Li Q: The combination therapy of salinomycin and gefitinib using poly(d,l-lactic-coglycolic acid)-poly(ethylene glycol) nanoparticles for targeting both lung cancer stem cells and cancer cells. OncoTargets Ther 10: 5653-5666, 2017.
Received May 17, 2018

Revised June 13, 2018

Accepted June 14, 2018 